\title{
Chinese Diplomatic Discourse for Europe: A Change of Style
}

Nikolay V. Litvak, Natalia B. Pomozova

\author{
Nikolay V. Litvak \\ Moscow State Institute of International Relations (MGIM0), Russia \\ International Law Faculty \\ Department of Philosophy \\ Professor \\ ORCID: 0000-0003-1621-0005 \\ E-mail:jourfr@mail.ru \\ Address: 76 Vernadsky Prospect, Moscow 119454, Russia \\ Natalia B. Pomozova \\ Russian State University for the Humanities, Moscow, Russia \\ School of History, Political Science and Law \\ Assistant Professor \\ ResearcherID: AAE-3313-2020 \\ ORCID: 0000-0002-9981-0593 \\ E-mail:npomozova@mail.ru \\ Address: 21 Vysokaya Str., Moscow 115533, Russia \\ DOI: $10.31278 / 1810-6374-2021-19-1-50-69$
}

\begin{abstract}
New means of information warfare are now used to achieve new goals, namely, cultural dominance and, as a result, control of other states and peoples. In this respect, more and more attention has recently been paid to the changing content and form of public communications by Chinese politicians, including diplomats. The article studies the speeches of Chinese ambassadors in key European countries (Germany, France, Great Britain, and Italy) on two issues for which Chinese policy has lately drawn most of the
\end{abstract}


Western criticism: the situation in Hong Kong and the COVID-19 pandemic. To determine the dynamics of the diplomatic discourse, speeches made between 2013 and mid-2020 were selected for analysis. The study is novel in that it tests the comprehensive analysis methodology, in particular Michel Foucault's concept of discourse in combination with Jacques Derrida's concept of deconstruction. The analysis made points to the change in the style of the Chinese diplomats' communication towards its "mediatization," preference to appeal directly to the European media and general public, doing so skillfully and with scientific substantiation.

Keywords: China, Chinese diplomacy, discourse, rhetoric, information warfare.

\section{INTRODUCTION}

The diplomatic language as the language of negotiators seeking an agreement between the heads of state who authorized them to do so is traditionally considered correct and elegant, but it also involves the so-called ("diplomatic") understatement and omissions, due to both restraint and excellent training of the speakers (ambassadors), and the extreme importance of the topics they discuss. Despite various, including critical, opinions, diplomatic work and diplomats are in great demand today. This is due to the current state of international relations: Parity in weapons of mass destruction, achieved in the standoff between the U.S. and the USSR after World War II, continues to deter a new international armed conflict, shifting the ongoing confrontation between global players into the information sphere. But the already large-scale and ever-growing information warfare clearly shows the conflictual nature of the current global situation. This war increasingly uses new means produced by modern science and industry, and its new main goal is to achieve victory in the form of cultural dominance and, as a result, control of other states and peoples (Litvak and Shestopal, 2017, p. 39).

The new terminology regarding Chinese diplomacy-'wolf warrior' diplomats and 'wolf warrior' diplomacy-comes from the name of a feature film about Chinese commandos rescuing their fellow citizens. It is consistent with the current Chinese propaganda policy which often 
uses words that stand in stark contrast to the traditional diplomatic vocabulary. Such a diplomatic style, not characteristic of China until recently, is a subject of controversy in the Chinese expert circles as some support tough rhetoric and relevant foreign policy (Xie, 2017), while others, on the contrary, believe that China should be more reserved on the international stage (Deng, 2020).

Since the spring of 2020, Western media have been actively using this terminology with regard to Chinese diplomats and diplomacy. In this context, some observers started to talk about Michel Foucault's concept of discourse, especially in relation to the struggle for power, which is, indeed, mentioned in official Chinese documents. The main vector of modern international politics is all-round confrontation between China and the United States. The two are engaged in an unequal struggle for the minds, hearts and capital of European countriesWashington's traditional allies. This is why the study focuses on four European countries, which are among the key EU members. In order to clarify the nature of such changes and their causes, we analyzed the speeches of Chinese ambassadors in key European countries (Germany, France, Great Britain, and Italy) from 2013 to the middle of 2020. This period was chosen because this is when-2013 and 2014-China started to actively advance its main modern foreign policy concepts, such as the Community of Common Destiny for Mankind and One Belt One Road, which almost immediately met the increasingly growing resistance in the West. For our research we used an array of Chinese ambassadors' statements as direct speech in official presentations and interviews is more reserved than posts in social media. The subject of the statements mainly concerned two issues that have drawn most of the Western criticism lately-the situation in Hong Kong since 2013 and the COVID-19 pandemic since 2020 (the list also includes the human rights situation in China and the growth of Chinese economic and technological dominance, but these issues are more or less similar to those discussed in this article). While the Hong Kong issue has been around longer and COVID-19 is now high on the agenda, both are, in our view, equally indicative of the changes taking place in the communication practices employed by China's top diplomats. 
Amid the rapid development of Chinese digital diplomacy, social networks are undoubtedly an important and very specific channel of communication. However, an analysis of Chinese ambassadors' discourse on social media requires a separate study. This article focuses on official sources quoting Chinese ambassadors' speeches and interviews published on embassy websites and in authoritative media.

In our study we used a methodology that combines Michel Foucault's concept of discourse and Jacques Derrida's concept of deconstruction, which have had a significant impact on the formation of modern diplomatic discourse in China.

\section{RESULTS}

The study has shown that from 2013 to mid-2020, the communication practices of the Chinese ambassadors in four European countries (Germany, France, Great Britain, and Italy) underwent a significant change in both content and intensity. There was a sharp increase in the number of materials featuring the ambassadors' interviews and direct speech in the host countries. They contained a large number of words and phrases that can be described as unofficial or colloquial (such as "pro-American advocates of 'international standards", "anti-Chinese defamation accusations," "to make political capital"). Although not rude, they are still unusual for the diplomatic parlance of recent decades.

Table 1. The number of materials with ambassadors' direct speech (interviews, remarks, comments) posted on the websites of Chinese embassies

\begin{tabular}{|l|c|c|c|c|}
\hline & $\begin{array}{c}\text { Number } \\
\text { of materials } \\
\text { in } 2014\end{array}$ & $\begin{array}{c}\text { Number } \\
\text { of materials } \\
\text { in } 2019\end{array}$ & $\begin{array}{c}\text { Number of materials } \\
\text { in the first half of } \\
2020\end{array}$ & $\begin{array}{c}\text { Chinese diaspora } \\
\text { (thous. people) }\end{array}$ \\
\hline Great Britain & 48 & 96 & 76 & 400 \\
\hline Germany & 11 & 8 & 10 & 309 \\
\hline Italy & 12 & 12 & 18 & 305 \\
\hline France & 4 & 26 & 32 & 600 \\
\hline
\end{tabular}

The immediate reason that triggered these changes was sharp criticism of Chinese policies at the beginning of the COVID-19 pandemic, 
followed by similar changes with regard to other acute issues in relations between the West and China.

Liu Xiaoming, the Chinese ambassador to the UK since 2010 (the only one of the four ambassadors in question who was not replaced in 2019), actively uses Twitter, and most of his current publications are quite sharp and concern not only the UK, but also the U.S. (Liu, 2020). Historically, one of the acutest issues in Sino-British relations is the situation in Hong Kong, where the transition period of reunification with China ending in 2047 occasionally suffers bouts of political aggravation. In 2014, demonstrations against mainland China's intention to control local elections lasted seventy-nine days and caused a significant international outcry. While U.S. President Barack Obama's comments were rather reserved, emphasized the internal nature of the problem and denied any U.S. involvement (Kwong, Ng, 2019), the British Foreign Office's position was stated in a stronger, albeit diplomatic, way voicing concern about the situation (BBC, 2014).

In response, Liu Xiaoming published an article in the Financial Times (Liu, 2014), explaining Beijing's position in connection with the protests in Hong Kong. The article was written in the traditional diplomatic style, the sharpest phrase being "pro-American advocates of 'international standards.' On November 21, 2016, the Daily Telegraph published another of his articles, which appeared in response to a new volley of criticism in the Western press. In the article titled "Oath Deniers Are Violating Hong Kong's Law” (Liu, 2016), the ambassador explained, in a fairly reserved manner typical of Chinese diplomacy, Beijing's position that members of the Hong Kong Legislative Council had to take an oath.

In 2017, in addition to a solemn speech at the Embassy reception on the occasion of the 20th anniversary of the transfer of sovereignty over Hong Kong to China, Liu Xiaoming gave a detailed interview to a critical $\mathrm{BBC}$ radio reporter. In the interview, the ambassador repeatedly emphasized the success of the "One Country, Two Systems" principle, the indivisibility of China as one of its fundamental interests, and the lack of superpower ambitions in Beijing (Liu, 2019a). In 2019, Liu Xiaoming gave three big news conferences devoted to large- 
scale protests that began on June 9, 2019, over the draft extradition law, which activists viewed as "a violation of Hong Kong's legitimate autonomy and the danger of spreading China's harsh totalitarian policy to the region" (Pomozova, 2019a). The ambassador's rhetoric had changed noticeably to include such previously unused phrases as "some reports... are even ill-willed slander," "hands off Hong Kong, show respect for what has been achieved in Hong Kong under 'One Country, Two Systems"' "I hate to comment on their [British politicians'] quotes," and "Western media have inescapable responsibility for the current situation in Hong Kong!” (Liu, 2019a; 2019b; 2019c; 2019e).

After the outbreak of the crisis caused by COVID-19 and the West's criticism of the Chinese government's policy in this regard, the Chinese ambassador to the UK followed two main tracks in his communications. He emphasized the need for close cooperation between London and Beijing in the face of a common threat and rejected accusations against his country in connection with the spread of COVID-19. In the latter case, Liu Xiaoming used a new, sharper terminology, calling politicians in the United States and Great Britain distributors of false information ("some politicians in the United States and here in this country, however, are spreading lies and stigmatizing China") (Liu, 2020a; 2020b; 2020c).

The Chinese ambassador to Germany, Shi Mingde, spoke rarely in 2012-2019 and whenever he did, he always used the traditional diplomatic language (Shi, 2019). His replacement, Wu Ken, immediately showed increased activity, although it was objectively provoked by another escalation of tension in Hong Kong. Commenting on the meetings of some German politicians with protest leaders, he, in particular, warned that they "will have negative consequences for Sino-German relations, and China has to respond" (Wu, 2019). His speeches began to be spiced with increasingly sharp phrases, such as "Your hidden political intentions are very dubious," "some German politicians... want to make political capital out of this" or "international media are behind the chaos in Hong Kong" (Wu, 2019). And yet, in response to accusations by the collective West that China is responsible for the spread of COVID-19, Wu Ken regularly makes statements filled 
with positive diplomatic rhetoric, emphasizing China's effective crisis management measures (Wu, 2020a; 2020b; 2020c; 2020d; 2020e), but assumes a more offensive manner when he wants to rebuff the criticism of China (Sigmund, 2020).

Germany, the unconditional leader of the European Union, is China's fourth largest trading partner in the world and first in Europe, as well as the main center of attraction for Chinese investments on the European continent.

In 2019, at his first news conference on the situation in Hong Kong, Chinese Ambassador to Italy Li Junhua, in contrast to his predecessor Li Ruiyu, called on "mysterious architects of the unrest not to play with fire" (Li, 2019a), and subsequently used such words as "condescension and connivance" by Western countries (Li, 2020a), and expressed his "strong dissatisfaction and disappointment." With the outbreak of the COVID-19 pandemic, in addition to the active use of Twitter, Facebook, and eventually Instagram, Li Junhua makes regular statements and gives interviews, emphasizing, on the one hand, China's solidarity with Italy and the need to join forces in the fight against the pandemic, and on the other hand, rejects criticism of China, using such phrases, never heard of him before, as "flinging mud at China," "use COVID-19 to slander China" (Seaman, 2020), "point the finger of scorn at China's help," "Mike Pompeo's observations are often erroneous" or "a critical point [in Sino-American relations]" (Li, 2020a; 2020b; 2020c).

The Chinese ambassador to France, Lu Shaye, also took up his new duty in July 2019 and since then has been acting, perhaps, most professionally among all of his abovementioned colleagues. His distinctive quality and advantage is that he always comes up with sound arguments regarding both what happens in general and specific cases of criticism against China, as well as some theoretical generalizations that strike a chord particularly in France, not without reason, though.

First of all, Lu Shaye draws a clear distinction between the authorities and the media, which, unlike the authorities and the peoples of Western countries, are (as he believes) the source of misunderstanding between countries, and their publications on Hong 
Kong represent an "obvious interference in the internal affairs of China." He repeatedly notes that "the media mislead the public in Western countries. Since the media do not provide the public with the whole truth, but choose several so-called truths" (matching their political views) (Lu, 2019c), their reports about the situation in Hong Kong are "barely objective" and, "to put it mildly, puzzling," "repeating a lie a thousand times does not make it true" ( $\mathrm{Lu}, 2019 \mathrm{a})$, and "the French and Western media in general are biased" (Lu, 2019b).

Lu Shaye's statements became even stronger with the outbreak of a pandemic in 2020, but at the same time he also used stronger arguments. So, while emphasizing that "the medical, at most sociomedical, problem of the viral epidemic is politicized," he points out that earlier, in a number of previous COVID-19-like cases (namely, the H1N1 influenza virus in 2009, MERS infection in 2012, Ebola in 2015, and SARS in 2003), no such politicization took place, but on the contrary, Europe and China fruitfully worked together to fight the diseases. The ambassador also cited the chronology of a mood swing in Western public opinion and the media from sympathy for China at the beginning of the epidemic to the calls to "make it pay" (Lu, 2020a).

The ambassador believes that this media "war" was generated by the United States and politicians who use it, firstly, in the struggle among themselves, i.e. in domestic American politics, and secondly, in order to weaken China, which they now consider their main strategic rival. And while neither European parties nor official agencies, just like most entrepreneurs and experts, never blamed China and showed restraint, the European media, on the contrary, fully sided with the United States, spreading anti-Chinese "slanderous accusations" (Lu, 2020a) (Lu Shaye, nevertheless, praised some rare publications in Le Monde and AFP for objectivity)

Speaking of contemporary Chinese diplomacy, the ambassador rejects media clichés characterizing it as "offensive" and "aggressive" and uses instead the words "active" and "completely defensive, only responding to attacks from Western media" (Lu, 2020b). Lu Shaye explained the changes in diplomatic rhetoric, so much talked about lately, by the weakness of the Chinese media in the West, which was the 
reason why Chinese diplomats had begun more active communication with the public of the host countries in order to protect the image of China and its national interests in confronting the "lies" spread by Western media, "propaganda" and, in fact, "brainwashing." European media are also criticized for not being independent and for following Washington which is responsible for rumors and lies about China. The ultimate generalization is as follows: "Statements which call China 'harsh' and 'aggressive' are pure lies invented by the United States in order to curb China's development and sow discord between China and its neighbors" (Lu, 2020b). Finally, Ambassador Shaye personally reacted in the same vein to the "wolf warrior" label being put by Western media on Chinese diplomats: "We react with facts and arguments, and do not fabricate lies or slander" (Lu, 2020b).

\section{DISCUSSION}

Since the fall of 2019 and especially the spring of 2020, the Chinese ambassadors in the four cases considered above (in key European capitals) have become much more active in their public appearances and changed their messages significantly. Most of the materials posted on the embassies' websites are an array of official impersonal press releases, statements, and communiqués that are interesting to specialists but are rarely read by the general public. However, now the embassies place the emphasis on speeches and interviews, since, in their opinion, local and international Western media provide their citizens with incomplete or distorted information. The status of ambassador also implies a second addressee, that is, the official authorities in each of the host countries. So, the diplomats not only make attempts, rather traditional, in the "soft power" style, to directly influence public opinion in France or Italy on a particular issue which has been politically accentuated by Western media and governments, but also try to explain to these authorities the objective reasons for both the positions assumed by China and the West, and discourse, through which these positions are expressed and largely formulated (according to Foucault).

The strengthening of China in the economic, technological, military, and other areas prompts Beijing to move away from a "modest" and 
wait-and-see foreign policy. This in itself constitutes the context that has made it possible for China to build its new diplomatic discourse.

London, the fourth largest importer from China, was the first among the G7 countries to join the Asian Infrastructure Investment Bank in 2015. It keeps its market open for Chinese investment (Pomozova, 2019) and considers China one of the most important export destinations, while Britain's exit from the European Union opens up new opportunities for a more independent economic policy towards China. Germany is China's fourth largest trading partner in the world and first in Europe, as well as the main center of attraction for China's investments on the European continent. For France, China is not just an important trade and economic partner, President Macron has openly called it one of the centers of the modern bipolar world. Italy was the first of the EU founding countries and the only G7 member to have signed a memorandum in support of the Belt and Road Initiative. During the COVID-19 pandemic China has actively provided humanitarian aid to all four countries: facial masks, gloves, protective suits, etc. (aid to Italy which was hit the hardest received wide response) (Seaman, 2020).

However, the context in which Beijing's diplomatic rhetoric is changing in the four countries under consideration also involves significant disagreements on a number of fundamental issues (understanding of human rights and values, sensitive high-tech issues), as well as the significant factor of pressure from the United States, all of which often act as serious irritants in bilateral relations with China (suffice it to recall the British government's decision to prohibit Huawei from deploying $5 \mathrm{G}$ networks in the country).

The discourse in the modern scholarly literature on sociopolitical problems has gradually become one of the main subjects and even objects of research. This is happening because communication between actors occurs mainly in the form of texts composed of statements that are viewed as signs of relevant positions, interests, plans or meanings. In addition, the current political and philosophical development of the concept of discourse (formulated first by linguists) makes it possible to build hypotheses, which are then tested by observing the development of 
real situations, regarding the untold, that is, something that determines the stated, specific discourse of specific sociopolitical actors.

This approach is based on Michel Foucault's concept of discourse as verbal representation of reality, expressed in specific, historically determined and existing statements, the totality of which constitutes an objective form and the framework of such representation.

In this context, some authors view the latest developments as a new Chinese discourse in action, and on top of it all in the Foucaultian interpretation, i.e. as a discourse-power relationship, which indeed has repeatedly been mentioned in official Chinese documents. However such an interpretation differs from Foucault's original concept and actually equates discourse with rhetoric, narrative and, therefore, an instrument of soft power or information warfare.

For example, such an interpretation is favored by Igor Denisov, who studies the Chinese "international discursive power" in detail. He believes, not without reason, that Chinese officials understand and adapt the French philosopher's concept in a simplified or rather utilitarian way (Denisov, 2020). L. Hagström and A. Nordin, who study the influence of Foucault's ideas not only on the authorities but also on Chinese intellectuals trying, among other things, to harmonize Confucianism with modernity, including Foucault's concept, also write about Beijing's understanding of discourse mainly in the context of soft power (Hagström and Nordin, 2020). B. Gill believes that Chinese soft power is relatively weak, and in search of a way out of the current situation, Beijing will opt for wolf warrior diplomacy (Gill, 2020).

However, the novelty of Foucault's approach is that it objectified discourse, proved that it is independent from the subject (unlike, for example, rhetoric), who does not arbitrarily learn about the world and puts his knowledge into statements, an array of which makes up discourse, as Foucault maintains. Therefore, "power is not something that is acquired, seized or shared, something that one holds on to or allows to slip away..." (Foucault, 1996), but what is constantly produced in the subject's statements and discourse.

It is important that, as one can gather from public materials, hard work is underway in China to grasp this and other concepts, and 
explore them in a creative and scholarly way. In particular, the state information resource clearly shows the objective understanding of the problem: "Many believe that the strength of international discourse is directly proportional to national power. For example, the United States is the most powerful country in the world today, and it also has the most powerful international discourse. Therefore, at present, China does not need a strategy for the development of international discourse... [since with the growth of] economic, military and other national power, China's international discourse will naturally become stronger" (PRC SCIO, 2017).

But it also contains counterarguments, referring specifically to situations where "the power of international discourse does not correspond to the strength of the country," depending, for example, on whether or not certain countries are able to raise problems or act by high moral principles. Then the discourse of small states can be stronger than their objective potential, and that of bigger states can be weaker (PRC SCIO, 2017). In other words, it introduces the factor of conscious strategy and policy with regard to both perceiving objective reality and managing the corresponding discourse. Chinese political scientist Zhao Kejin shows Beijing's appeal to discursive power in international relations after Xi Jinping's election in precisely this way-discourse-knowledge, in conformity with Foucault's approach. This implies not just a change of rhetoric, but the establishment of facts and the introduction of innovative rules and practices in the social sphere. This is done by highlighting in external communications not so much China's five-thousand-year-long history (which underlies its soft power) as its latest achievements in high technology and activity in international institutions (Zhao, 2016).

It is the objective nature of discourse that should be taken into account when interpreting Lu Shaye's remarks about the difference between China and the West in their approaches to human rights, which "still exist" due to their historicity - gradual formation and development in different countries with different "national situations." Therefore, human rights are values in China, too, and no one, the West in the first place, can be a judge in this matter and evaluate others on a "better or worse" scale (Lu, 2020c). 
The use of the deconstructive approach for the analysis of the statements being considered (Derrida, 1967) brings us closer to understanding what is implied, but not told in specific texts, which appear to be lacking a clear structure and utilizing ambiguous word signs used by different actors in different contexts. This means, in particular, that the mention of Foucault by the Chinese in their official discourse does not yet indicate, but already implies, a step towards understanding the substance of the problems in their communication with the modern West, which formed under the objective influence of historical differences in national discourses.

Europeans note, quite rationally, the differences between their own and the Chinese understanding of human rights (Worden, 2019, p.9), but reduce them completely to subjective, voluntaristic factors, attributing them solely to political and ideological differences (insisting that China should understand and realize this...). For their part, the Chinese become increasingly aware that their understanding of human rights and disagreements with Europeans have developed historically for certain objective reasons that Europeans fail to see. This is why the Chinese ambassadors appeal to European rationality in order to explain their understanding of the problem and emphasize the concepts they would like to see at the heart of bilateral, multilateral, and international relations (multipolarity, equality and mutual respect, non-interference). And even the constant emphasis on differences (we are different) is a rational appeal to multiculturalism, which is advocated by present-day European leaders, albeit sometimes in spite of many of their voters.

Chinese theorists and practitioners are vigorously reflecting and acting to test the verity of the obtained knowledge about the West, themselves and the world as a whole, in much the same way social reflexive institutions emerging in the West are doing (Litvak, 2018). Reducing changes in their communications to the use of sterner, bordering on non-diplomatic, wording, and labeling Chinese diplomats as "wolf warriors" in the war unfolding in the media space would be an unjustified simplification. First of all, this label describes the process that started with a dust-up on American social media (originally on 
Twitter) in the summer of 2019 between the Americans (including Barack Obama and Condoleezza Rice) and Minister Counsellor at the Chinese Embassy in Pakistan Zhao Lijian over Washington's critical statements on human rights in China. The Chinese diplomat pointed to their own, including racial, problems in the United States. Subsequently many diplomats and Chinese Foreign Ministry senior officials spoke actively on Western social media to reject the criticism of their government.

\section{CONCLUSIONS}

Since the end of 2019, Chinese ambassadors in Europe, just like Chinese Foreign Ministry top officials, have been actively "mediatizing" their communications, using both academic reasons (including Foucault's concept of discourse) and diplomatic art. So we can talk about a new Chinese experience, that is, the use of ambassadors and high-ranking government representatives with a very specific status-neutral and communicative-for defensive (critical, explanatory) and offensive communication with the society of the host countries through their own, domestic media channels.

The rhetoric of Chinese ambassadors at public appearances has changed; they have expanded their vocabulary to include, in addition to diplomatically oblique phrases, explicit terms describing their negative assessment of Western criticism. As for discourse, defining changes in it would depend on what exactly is meant by discourse and within which concept it is considered. Adhering to the linguistic approach, we can say that discourse has changed. However, the sociopolitical and philosophical approaches, such as that of Foucault, widely cited in this context, and that of Derrida, prompt further conclusions.

From this point of view, firstly, (according to Foucault) discourse is not something that can be consciously controlled or fought, etc., but the framework within which actors of a specific sociopolitical nature explore the world and themselves in it and express their knowledge. In other words, in terms of understanding discourse, what the Chinese ambassadors say in this case is objectively determined by what China is like today and how it explores and understands itself. 
Secondly, (according to Derrida) even with this in mind, the Chinese ambassadors in Europe turn to European rationalism, which today guides the political authorities in its key countries, in order to draw their attention to academic positions formulated, above all, by European scholars, which suggest that the European reaction to China's development and its proposal for joint work is unnecessarily politicized-unnecessarily because a significant part of what is happening, including what is said, has objective grounds.

Subjective plans of communist China for the world, let alone its "intrigues" as an object of Western discourse, throw the West into a conspiracy fervor.

Meanwhile, an analysis of the discourse showed that the Chinese ambassadors in the four key European countries continue to develop their diplomatic skills, relying, among other things, on Western philosophical concepts. Needless to say, it would not be quite appropriate to apply the ideologized cliché "wolf warriors" to highly qualified Chinese diplomats.

\section{References:}

BBC, 2014. Hong Kong Protests: UK 'Concerned' about the Situation. BBC, 29 September [online]. Available at: $<$ www.bbc.com/news/uk-29411128> [Accessed 12 August 2020].

Deng, Yuwen, 2020. Kezuo pinglun: Zhongguo waijiao, hui bu qu de "taoguanyanghui" [Guest Commentary: China's Diplomacy Can't Go Back to "Hiding Capacities and Maintaining a Low Profile"]. Deutsche Welle, 26 March [online]. Available at: <www.dw.com/zh/\%E5\%AE\%A2\%E5\%BA\%A7\%E8\%A F\%84\%E8\%AE\%BA\%E4\%B8\%AD\%E5\%9B\%BD\%E5\%A4\%96\%E4\%BA\%A4 \%Е5\%9B\%9E\%E4\%B8\%8D\%E5\%8E\%BB\%E7\%9A\%84\%E9\%9F\%AC\%E5\%8 5\%89\%E5\%85\%BB\%E6\%99\%A6/a-52921981> [Accessed 11 December 2020].

Denisov, I., 2020. Kontseptsiya "diskursivnoi sily" i transformatsiya kitayskoi vneshnei politiki pri Si Tszinpine [The Concept of "Discursive Power" and the Transformation of Chinese Foreign Policy under Xi Jinping]. Sravnitel'naya politika, 11(4) [online]. Available at: <doi.org/10.24411/2221-3279-2020-10047> [Accessed 20 November 2020]. 
Derrida, J., 1967. L’écriture et la différence. Editions du Seuil [Writing and Difference].

Foucault, M., 1996. Volya $k$ istine: po tu storonu znaniya, vlasti i seksual'nosti. Raboty raznykh let. [Will to Truth: Beyond Knowledge, Power and Sexuality. Works of Different Years]. Moscow: Kastal.

Gill, B., 2020. Diplomatiya "volkov-voinov" v Kitaye - rabotayet li ona? [Diplomacy of "Wolf-Warriors" in China - Does It Work?]. Rossiya v global'noi politike [online]. Available at: <globalaffairs.ru/articles/diplomatiya-volkovvoinov> [Accessed 20 November 2020].

Hagström, L. and Nordin, A., 2020. China’s "Politics of Harmony" and the Quest for Soft Power in International Politics. International Studies Review, 22(3), September, pp.507-525 [online]. Available at: <doi.org/10.1093/isr/viz023> [Accessed 20 November 2020].

Kwong, Man-ki and Ng, Kang-chung, 2019. US Has No Involvement in Fostering Occupy Protest, Obama Tells Xi. South China Morning Post, 12 November [online]. Available at: <www.scmp.com/news/hong-kong/article/1638128/us-has-noinvolvement-fostering-occupy-protest-obama-tells-xi> [Accessed 12 August 2020].

Li, Junhua, 2019a. Conferenza stampa dell'Ambasciatore Li Junhua sulla situazione attuale a Hong Kong [Press conference by Ambassador Li Junhua on the Current Situation in Hong Kong]. 12 August [online]. Available at: <it.chinaembassy.org/ita/xwdt/t1688146.htm> [Accessed 17 August 2020].

Li, Junhua, 2019b. Tensioni a Hong Kong, lo stato di diritto e la via del dialogo [Tensions in Hong Kong, the Rule of Law and the Path of Dialogue]. Il Messaggero, 31 August [online]. Available at: <www.ilmessaggero.it/mondo/ hong_kong_proteste-4704630.html> [Accessed 17August 2020].

Li, Junhua, 2020a. Ambasciatore cinese: "Gli aiuti? Siamo amici, vogliamo salvare vite" [Chinese Ambassador: "Help? We Are Friends, We Want to Save Lives"]. Adnkronos [online]. Available at: <www.adnkronos.com/fatti/esteri/2020/04/05/ ambasciatore-cinese-all-adnkronos-gli-aiuti-siamo-amici-vogliamo-salvarevite_7k6IDKelqCqooYvrZREMbN.html> [Accessed 18 August 2020].

Li, Junhua, 2020b. Cina. Ambasciatore Li: Noi trasparenti sin dall'inizio, consenso Xi-Trump unica scelta giusta possibile [China. Ambassador Li: We Are Transparent from the Start, Xi-Trump Consensus Is the Only Right Choice Possible] [online]. Available at: <www.scenari-internazionali.com/cinaambasciatore-li-noi-trasparenti-sin-dallinizio-consenso-xi-trump-unica-sceltagiusta-possibile/> [Accessed 18 August 2020]. 
Li, Junhua, 2020c. Dichiarazione del portavoce dell'Ambasciata della Repubblica Popolare Cinese in Italia in merito alle dichiarazioni di alcuni politici italiani su Hong Kong [Statement by the Spokesman of the Embassy of the People's Republic of China in Italy Regarding the Statements of Some Italian Politicians on Hong Kong] [online]. Available at: <it.china-embassy.org/ita/xwdt/t1794443. htm> [Accessed 14 August 2020].

Litvak, N. and Shestopal, A., 2017. Rol' kul'tury vo vneshnei politike novoi Rossii [The Role of Culture in the New Russian Foreign Policy]. Concept: Philosophy, Religion, Culture, Vol. 3 [pdf]. Available at: <https://concept.mgimo.ru/jour/ article/viewFile/87/69> [Accessed 20 January 2021].

Liu, Xiaoming, 2016. Oath Deniers Are Violating Hong Kong's Law. The Telegraph, 20 November [online]. Available at: <www.telegraph.co.uk/ news/2016/11/20/oath-deniers-are-violating-hong-kongs-law/> [Accessed 13 August 2020].

Liu, Xiaoming, 2019a. China Not Frightened of Dissent. BBC Radio4, 28 November [online]. Available at: <www.bbc.com/news/av/world-asiachina-50593441/ambassador-liu-xiaoming-china-not-frightened-of-dissent $>$ [Accessed 13 August 2020].

Liu, Xiaoming, 2019b. China Will Never Tolerate Any Challenge to the Bottom Line of "One Country, Two Systems". Chinese Embassy in UK official website, 16 August [online]. Available at: <www.chinese-embassy.org.uk/eng/ambassador/ dsjhjcf/2019dashijianghua/t1689700.htm> [Accessed 13 August 2020].

Liu, Xiaoming, 2019c. Ambassador Liu Xiaoming Holds a Press Conference on the Situation in Hong Kong. Chinese Embassy in UK official website, 16 August [online]. Available at: <www.chinese-embassy.org.uk/eng/tpxw/t1689696.htm> [Accessed 13 August 2020].

Liu, Xiaoming, 2019d. Keynote Speech by H.E. Ambassador Liu Xiaoming at the Young Icebreakers 11th Anniversary Dinner. Chinese Embassy in UK official website, 9 November [online]. Available at: <www.chinese-embassy.org.uk/eng/ ambassador/dsjhjcf/2019dashijianghua/t1714547.htm > [Accessed 13.08.2020].

Liu, Xiaoming, 2019e. Ambassador Liu Xiaoming Holds the Third Press Conference on the Situation in Hong Kong at the Chinese Embassy. Chinese Embassy in UK official website, 18 November [online]. Available at: <www. chinese-embassy.org.uk/eng/ambassador/dsjhjcf/2019dashijianghua/t1716770. htm> [Accessed 13 August 2020]. 
Liu, Xiaoming, 2020a. British People Blame Chinese Government More Than Their Own for the Spread of Coronavirus. The Conversation, 6 May [online]. Available at: $<$ theconversation.com/british-people-blame-chinese-governmentmore-than-their-own-for-the-spread-of-coronavirus-137642> [Accessed 20 December 2020].

Liu, Xiaoming, 2020b. Twitter Account [online]. Available at: <twitter.com/ ambliuxiaoming $>$ [Accessed 18 August 2020].

Liu, Xiaoming, 2020c. Disperse Lies with Trust and Beat the Virus with Cooperation. Evening Standard, 27 April [online]. Available at: <www.standard. co.uk/comment/comment/disperse-lies-with-trust-and-beat-the-virus-withcooperation-a4409231.html> [Accessed 13 August 2020].

Liu, Xiaoming, 2020d. Reform in Hong Kong Must Follow the Basic Law. Financial Times, 9 July [online]. Available at: <www.chinese-embassy.org.uk/ eng/ambassador/dsjhjcf/2014/t1172683.htm> [Accessed 12 2019].

Lu, Shaye, 2019a. Ambassadeur de Chine en France publie un article dans Le Figaro: La liberté ne peut justifier la violence et la démocratie n'est pas une excuse pour les émeutiers. Chinese Embassy in France official website, 3 May [online]. Available at: <www.amb-chine.fr/fra/zfzj/t1694149.htm > [Accessed 24 November 2020].

Lu, Shaye, 2019b. Interview de S.E.M. Ambassadeur de Chine en France par des médias de langue chinoise en France. Chinese Embassy in France official website, 14 August [online]. Available at: <www.amb-chine.fr/fra/zfzj/t1693879.htm> [Accessed 24 November 2020].

$\mathrm{Lu}$, Shaye, 2019c. Interview de l'Ambassadeur Lu Shaye par L'Opinion. Chinese Embassy in France official website, 12 December [online]. Available at: <www. amb-chine.fr/fra/zfzj/t1723747.htm> [Accessed 24 November 2020].

Lu, Shaye, 2020a. Allocution de l'Ambassadeur à l'occasion du Dialogue sur la Chine et le monde d'après la COVID-19. Chinese Embassy in France official website, 12 June [online]. Available at: <www.amb-chine.fr/fra/zfzj/t1788135. htm $>$ [Accessed 24 November 2020].

$\mathrm{Lu}$, Shaye, 2020b. Interview accordée par l'Ambassadeur Lu Shaye à L'Opinion. Chinese Embassy in France official website, 29 April [online]. Available at: <www. amb-chine.fr/fra/zfzj/t1774696.htm> [Accessed 19 November 2020].

Lu, Shaye, 2020c. Questions-réponses lors de la conférence de presse donnée par l'Ambassadeur de Chine Lu Shaye. Chinese Embassy in France official website, 24 September [online]. Available at: <www.amb-chine.fr/fra/zgzfg/t1817634.htm> [Accessed 19 November 2020]. 
Lu, Shaye, 2020d. Allocution de l'Ambassadeur LU Shaye à l'occasion du Dialogue sur la Chine et le monde d'après la COVID-19. Chinese Embassy in France official website, 12 June [online]. Available at: <www.amb-chine.fr/fra/ zfzj/t1788135.htm> [Accessed 19 November 2020].

Ousselin, Edward, 2018. La France: histoire, société, culture. Toronto: Canadian Scholars.

Pomozova, N., 2019a. Bez litsa [Faceless]. Rossiya v global'noi politike, 7 August [online]. Available at: <globalaffairs.ru/articles/bez-licza/> [Accessed 13 August 2020].

Pomozova, N., 2019b. European Values and the Chinese Factor. Russia in Global Affairs, 18(1), pp.180-196. Available at: <eng.globalaffairs.ru/articles/europeanvalues-chinese-factor/> DOI: 10.31278/1810-6374-2020-18-1-180-196.

PRC SCIO, 2017. Guoji huayu quan jianshe zhong ji da jichu xing lilun wenti [Several Basic Theoretical Questions in the Construction of the Law of International Discourse]. [online]. Available at: <www.scio.gov.cn/zhzc/10/ Document/1543300/1543300.htm $>$ [Accessed 20 November 2020].

Price, Barclay, 2019. The Chinese in Britain-A History of Visitors and Settlers. UK: Amberley Books.

Seaman, J., 2020. Covid-19 and Europe-China Relations. A Country-Level Analysis. Special Report of ETNC. IFRI, 29 April [online]. Available at: <www. ifri.org/en/publications/publications-ifri/ouvrages-ifri/covid-19-europe-chinarelations-country-level-analysis> [Accessed 20 November 2020].

Shi, Mingde, 2019. In Hongkong herrscht höchste Autonomie. Deutschlsandfunk, 26 October [online]. Available at: $<w w w$.deutschlandfunk.de/chinas-botschaftershi-mingde-in-hongkong-herrscht-hoechste.868.de.html?dram:article_ $\mathrm{id}=301391>$ [Accessed 13 August 2020].

Sigmund, T., 2020. China’s Botschafter in Berlin: "Die Maßnahmen Chinas sind richtig und wirksam". Handelsblatt, 27 February [online]. Available at: <www. handelsblatt.com/politik/deutschland/wu-ken-im-interview-chinas-botschafterin-berlin-die-massnahmen-chinas-sind-richtig-und-wirksam-/25588692. html?ticket=ST-7788592-ud360YnGOcCcw9CNsate-ap6 $>$ [Accessed 14 August 2020].

Worden, A., 2019. The Human Rights Council Advisory Committee: A New Tool in China's Anti-Human Rights Strategy. Sinopsis: China in Context and Perspective, 6 August [online]. Available at: $<$ https://sinopsis.cz/en/wordenhuman-rights-council-advisory-committee/> [Accessed 13 August 2020]. 
Wu, Ken, 2019. China-Botschafter sperrt BILD-Reporter aus (Interview of Chinese Ambassador in Germany). Bild, 11 September [online]. Available at: $<$ www.bild.de/politik/ausland/politik-ausland/botschafter-greift-wong-scharfan-chinesen-sperren-bild-aus-64566406.bild.html> [Accessed 19 November 2020].

$\mathrm{Wu}, \mathrm{Ken}, 2020 \mathrm{a}$. Mit internationaler Hilfe kann die Krankheit besiegt warden. Der Tagesspiegel, 21 February [online]. Available at: <www.tagesspiegel.de/ politik/china-und-das-coronavirus-mit-internationaler-hilfe-kann-diekrankheit-besiegt-werden/25567244.html> [Accessed 14 August 2020].

$\mathrm{Wu}, \mathrm{Ken}, 2020 \mathrm{~b}$. Hand in hand aus Coronakrise. Chinese Embassy in Germany official website, 26 May [online]. Available at: <de.china-embassy.org/det/sgyw/ t1782864.htm > [Accessed 14 August 2020].

$\mathrm{Wu}, \mathrm{Ken}, 2020 \mathrm{c}$. China hat nichts zu vertuschen. ZDF, 23 April [online]. Available at: <www.zdf.de/nachrichten/zdf-morgenmagazin/wu-ken-chinahat-nichts-zu-vertuschen-100.html $>$ [Accessed 14 August 2020].

$\mathrm{Wu}, \mathrm{Ken}, 2020 \mathrm{~d}$. Botschafter Wu Ken im Interview mit junge Welt (Teil 2 und Schluss). Chinese Embassy in Germany official website, 5 March [online]. Available at: <de.china-embassy.org/det/dszl/dsjscf/t1752533.htm $>$ [Accessed 14 August 2020].

$\mathrm{Wu}, \mathrm{Ken}, 2020$ e. Botschafter WU Ken im Interview mit der Funke Mediengruppe. Chinese Embassy in Germany official website, 2 July [online]. Available at: <de.china-embassy.org/det/dszl/dsjscf/t1794171.htm> [Accessed 14 August 2020].

Xie, Tao, 2017. Xi Jinping tese de Znongguo waijiao zhengce [China's Foreign Policy with Xi Jinping Characteristics]. Carnegie-Tsinghua, 20 November [online]. Available at: <carnegietsinghua.org/2017/11/20/zh-pub-75390> [Accessed 13 December 2020].

Zhao, Kejin, 2016. China's Rise and Its Discursive Power Strategy. Chinese Political Science Review, Vol. 1, pp.539-564. DOI: doi.org/10.1007/s41111-0160037-8 [Accessed 22 November 2020]. 